\title{
PENGUATAN PENDIDIKAN KARAKTER \\ DALAM PEMBELAJARAN BERBASIS HOTS \\ CHARACTER EDUCATION STRENGTHENING \\ IN HOTS-BASED LEARNING
}

\author{
Aida Hayani \\ Pascasarjana UIN Sunan Kalijaga Yogyakarta \\ aidaalmahira@yahoo.com \\ Fauzi Fahmi \\ Pascasarjana UIN Maulana Malik Ibrahim Malang \\ fauzifahmi58@yahoo.com \\ Rida Chairani Putri Marpaung \\ Pascasarjana UIN Maulana Malik Ibrahim Malang \\ ridachairani62118@gmail.com
}

\begin{abstract}
The problematic phenomenon of the increasing cases of juvenile delinquency that arises today, both in terms of quantity and quality can be used as a measurement of the decline in ethics, morals and character of the nation as the originator of the golden generation of the future. This phenomenon certainly cannot be separated from the role of education, especially education in schools/madrasas. In connection with this phenomenon the government promotes the strengthening of character education to overcome existing problems. The current 2013 curriculum is a government effort to improve the existing system. Improvements are made by changing the content standards and process standards. The hope of the government with curriculum changes can help students to improve their ability to think creatively and innovatively at a high level in preparing young people who excel to face global challenges. This study aims to change the new paradigm in learning that emphasizes the strengthening of HOTS-based character education in order to produce superior generations of the digital age. This study used a qualitative approach with case study design. Data collection techniques through observation, interviews and documentation. High-level abilities can be realized by practicing through learning in the classroom. Supporting learning to improve the ability to think highly is through contextual and meaningful learning.

Keywords: Strengthening Character Education, Learning, HOTS
\end{abstract}




\begin{abstract}
Abstrak
Fenomena problematika meningkatnya kasus kenakalan remaja yang muncul dewasa ini, baik masa depan. Fenomena ini tentunya tidak dapat dilepaskan dari peran pendidikan terutama pendidikan di sekolah/madrasah. Berkaitan dengan fenomena tersebut pemerintah menggalakan penguatan pendidikan karakter untuk mengatasi permasalahan yang ada. Kurikulum 2013 yang diberlakukan saat ini merupakan usaha pemerintah untuk membenahi sistem yang ada. Penyempurnaan dilakukan dengan merubah standar isi dan standar proses. Harapan pemerintah dengan perubahan kurikulum dapat membantu peserta didik untuk meningkatkan kemmapuan berfikir kreatif dan inovatif tingkat tinggi dalam menyiapkan generasi muda yang unggul untuk menghadapi tantangan global. Penelitian ini bertujuan mengubah paradigma baru dalam pembelajaran yang menekankan penguatan pendidikan karakter berbasis HOTS guna mencetak generasi unggul era digital. Penelitian ini menggunakan pendekatan kualitatif dengan rancangan studi kasus. Teknik pengumpulan data melalui observasi, wawancara dan dokumentasi. Kemampuan tingkat tinggi dapat terwujud dengan berlatih melalui pembelajaran di dalam kelas. Pembelajaran yang mendukung untuk meningkatkan kemampuan befikir tinggi adalah melalui pembelajaran kontekstual dan bermakna.dari segi jumlah maupun kualitas dapat dijadikan sebagai alat ukur menurunnya etika, moral dan karakter anak bangsa sebagai pencetus generasi emas
\end{abstract}

Kata Kunci: Penguatan Pendidikan Karakter, Pembelajaran, HOTS

\title{
Pendahuluan
}

Keberhasilan suatu pendidikan terletak pada proses pembelajaran yang bermutu. Pembelajaran yang bermutu dapat terjadi melalui proses pembelajaran yang mampu berfikir tingkat tinggi (High Order Thinking Skill). ${ }^{1}$ High order thingking skill sebagai salah satu pilar dari keempat pilar kurikulum 2013 revisi 2017. Pada pilar tersebut meliputi penguatan pendidikan karakter, 4C (creative, critical, communication, collaboration), literasi dan high other thinking skill dalam pembelajaran harus mampu menanamkan nilai-nilai penguatan pendidikan karakter yang mampu mengadopsi high other thinking skill dalam pembelajaran. ${ }^{2}$

\footnotetext{
1 Merta Dhewa Kusuma Et Al., "The Development Of Higher Order Thinking Skill (Hots) Instrument Assessment In Physics Study," Iosr Journal Of Research \& Method In Education (Iosrjrme), 2017, Https://Doi.Org/10.9790/7388-0701052632.

2 Endang Komara, "Penguatan Pendidikan Karakter Dan Pembelajaran Abad 21," Sipatahoenan: South-East Asian Journal For Youth, Sports \& Health Education, 2018.
} 
Pendidikan karakter merupakan wadah bagi pencetus generasi emas masa depan yang memiliki etika dan moral yang terintegritas tinggi. etika dan moral yang diperoleh oleh peserta didik dalam pembelajaran dapat di ciptakan melalui penguatan pendidikan karakter. Penguatan pendidikan karakter itu sendiri melalui religius, nasionalis, integritas, gotong royong, dan mandiri. ${ }^{3}$ Dengan demikian pembelajar mampu menerapkan ke liama nilai penguatan pendidikan karakter dalam dirinya, masyarakat, nusa dan bangsa. Guna menerapkan nilai pendidikan karakter tersebut yang terealisasikan dalam pembelajaran yang mampu berfikir tingkat tinggi. berfikir tingkat tinggi dalam kurikulum 2013 era digital saat ini merupakan tolak ukur bagi pengemban bembelajaran.

Pembelajaran di desain semenarik mungkin kreatif dan inovatif sehingga pembelajar mampu berfikir secara kritis dalam pemecahan masalah. ${ }^{4}$ Pembelajar yang mampu berfikir kritis dapat meningkatkan daya nalar dan intelektualitas dirinya sebagai pribadi yang mencerminkan sosok manusia yang idealis. Proses demi prose, tahap demi tahap dilalui oleh pembelajar sebagai sosok idividu yang memiliki moralitas tinggi. ${ }^{5}$ Pada tahap pembelajaran seorang pembelajar mampu mendimensikan pemikirannya secara kolaboratif sehingga dapat menekankan berfikir tingkat tinggi terhadap dirinya secara kritis melalui penguatan pendidikan karakter.

Pembelajaran berbasis HOTS merupakan kunci mengubah paradigma pembelajara era digital. Pembelajar dalam penguatan pendidikan karakter yang menciptakan perubahan dalam peradaban yang beradap. Fenomena problematika meningkatnya kasus kenakalan remaja yang muncul dewasa ini, baik dari segi jumlah maupun kualitas dapat dijadikan sebagai alat ukur menurunnya etika, moral dan karakter anak bangsa sebagai pencetus generasi emas masa depan.

Hal demikian telah dibuktikan dengan adanya Lembaga survey LSM Plan International dan International Centre For Research on Women (ICRW) meenilai hasil survey bahwa angka kekerasan anak Indonesia mencapai berkisar

\footnotetext{
${ }^{3}$ Rasid Yunus, "Transformasi Nilai-Nilai Budaya Lokal Sebagai Upaya Pembangunan Karakter Bangsa," Jurnal Penelitian Pendidikan, 2016.

${ }^{4}$ Budi Cahyono, "Analisis Ketrampilan Berfikir Kritis Dalam Memecahkan Masalah Ditinjau Perbedaan Gender,” Aksioma, 2017, Https://Doi.Org/10.26877/Aks.V8i1.1510.

5 Nanda Ayu Setiawati, "Pendidikan Karakter Sebagai Pilar Pembentukan Karakter Bangsa," Seminar Nasional Tahunan Fakultas Ilmu Sosial Universitas Negeri Medan, 2017.
} 
84\% yang terjadi paling banyak pada lingkungan sekolah, hasil menunjukaan lebih tinggi dari kawasan Asia yang berkisar pada angka 70\%. ${ }^{6}$ Komisi Perlindungan Anak Indonesia (KPAI) pada hari pendidikan Nasional juga menyatakan terkait angka kekerasan yang dialami peserta didik Indonesia mencapai $84 \% .^{7}$

Krisis moral, etika dan karakter yang melanda peserta didik saat ini menjadi fenomena sosial krusial yang sangat memprihatinkan. ${ }^{8}$ Pertama, fenomena yang terjadi di Purwakarta pada hari Sabtu 21 April 2018 belasan siswa Sekolah Dasar kedapatan membawa senjata tajam yang diduga akan digunakan tawuran. Mereka akhirnya dikembalikan ke orang tuanya setelah dibina di Mapolsek Purwakarta, Jawa Barat. ${ }^{9}$ Kedua, kasus yang terjadi di Probolinggo pada hari Sabtu 26 Januari 2019 siswi Sekolah Dasar yang diperkosa oleh teman sekelasnya, kejadian tersebut dilakukan oleh dua orang pelaku yang memaksa si korban dan melakukan pemerkosaan di ruang kelas saat guru sedang izin tidak masuk. Salah seorang pelaku yang pernah tinggal kelas selama dua kali mengancam korban dengan pisau cutter. ${ }^{10}$

Dengan demikian perlu adanya dorongan yang kuat bagi peseta didik guna memperoleh hal yang positif dalam dirinya melalui penguatan pendidikan karakter dalam aspek pembelajaran yang menekankan pada High Order Thinking Skill. Proses tersebut ditindaklanjuti oleh adanya perubahan Kurikulum saat ini yang mengedepankan asoek afektif dari aspek yang lainnya secara berkesinambungan. Fenomena ini tentunya tidak dapat dilepaskan dari peran pendidikan terutama pendidikan di sekolah/madrasah.

Berkaitan dengan fenomena tersebut pemerintah menggalakan penguatan pendidikan karakter untuk mengatasi permasalahan yang ada. Kurikulum 2013 yang diberlakukan saat ini merupakan usaha pemerintah untuk membenahi sistem

\footnotetext{
6 Santy Andrianie, "Meningkatkan Keterampilan Empati Siswa Sekolah Dasar Melalui Paket Bimbingan Peningkatan Empati," Jurnal Bikotetik, Volume 01, Nomor 02, (2017): Hlm.67.

${ }^{7}$ Https://Databoks.Katadata.Co.Id/Datapublish/2017/02/10/84-Anak-Indonesia-Alami-KekerasanDi-Sekolah, Diakses Pada Tanggal 28 Oktober 2019 Pukul 15.48 Wib.

${ }^{8}$ Ririn Nursanti, "Manajemen Peningkatan Akhlak Mulia Di Sekolah Berbasis Islam", Jurnal Kependidikan, Vol. Ii, No. 2, (November 2014), 47

${ }^{9}$ Https://Www.Liputan6.Com/News/Read/3476521/Cegah-Tawuran-Siswa-Sd-Di-PurwakartaPolisi-Bakal-Pimpin-Upacara Diakses Pada Tanggal 20 Agustus 2019 Pukul 16.55

${ }^{10} \mathrm{Https}$ //Www.Liputan6.Com/News/Read/3880325/Siswi-Sd-Di-Probolinggo-Dicabuli-OlehDua-Teman-Sekelasnya. Diakses Pada Tanggal 20 Agustus 2019 Pukul 16.47 Wib.
} 
yang ada. Penyempurnaan dilakukan dengan merubah standar isi dan standar proses. ${ }^{11}$ Harapan pemerintah dengan perubahan kurikulum dapat membantu peserta didik untuk meningkatkan kemampuan berfikir kreatif dan inovatif tingkat tinggi dalam menyiapkan generasi muda yang unggul untuk menghadapi tantangan global.

Pada abad 21 era digital sata ini merupakan tantangan yang besar bagi penerus masa depan yang unggul dalam berbagai aspek yang produktif. Proses tersebut tidak terlepas bagi peran pemerintah dalam revilusi industry 4.0 yang secara cepat mampu berkontribusi dalam mengubah paradigma setiap peserta didik. Penelitian ini bertujuan mengubah paradigma baru dalam pembelajaran yang menekankan penguatan pendidikan karakter berbasis HOTS guna mencetak generasi unggul era digital.

\section{Metode Penelitian}

Jenis penelitian lapangan, case study, ini menggunakan pendekatan kualitatif naturalistik. Penelitian ini dilaksanakan selama kurang lebih 1 bulan mulai September s.d Oktober 2019. Tempat penelitiannya yaitu di SD IT Bunayya Lhokseumawe. Lokasi dipilih dengan tiga pertimbangan. Pertama, telah tiga kali berturut-turut mendapat pengakuan akreditasi program studi 'A". Kedua, orientasi pengembangan keilmuannya jelas.

Subjek penelitian ini terdiri dari key informant pangkal adalah Kepala Sekolah, sedangkan informan penelitian ini adalah Guru PAI dan Siswa. Penentuan subjek penelitian dilakukan dengan purposive dan snowball sample. Artinya informan bertambah terus sampai informasi yang diperoleh memuaskan atau sudah tidak dapat bertambah lagi atau jenuh (redundancy).

Objek penelitian ini adalah pendidikan karakter berbasis HOTS di SD IT Bunayya Lhokseumawe. Prosedur penelitian dilakukan dengan empat langkah 1) pengumpulan data, 2) reduksi data melalui koleksi data, pengkodean data, danrefleksi data, 3) display data, dan 4) penarikan kesimpulan/verifikasi. Alat

\footnotetext{
11 Kemendikbud Ri, Press Workshop: Implementasi Kurikulum 2013, Kementrian Pendidikan Dan Kebudayaan Republik Indonesia (2014).
} 
pengumpul data atau instrument penelitian adalah peneliti sendiri (human instrument).

Peneliti terjun sendiri kelapangan secara aktif melakukan pengamatan langsung dan wawancara. Data diperoleh melalui observasi partisipatif, peneliti melakukan pengamatan dan pencatatan yang sistematis terhadap gejala-gejala yang diteliti, dan wawancara dilakukan secara bebas terkontrol. Dokumen yang terkait dengan penelitian ini berupa dokumentasi artifak, manuskrip yang berhubungan dengan pendidikan karakter di SD IT Bunayya Lhokseumawe. Model induktif digunakan dalam analisis data. Data yang sudah dikumpulkan kemudian dianalisis dengan menempuh empat komponen analisis interaktif, yakni pengumpulan data, reduksi data, display data, dan penarikan kesimpulan/verifikasi.

Pada tiap komponen berinteraksi dan membentuk sebuah siklus. ${ }^{12}$ Data yang di peroleh selanjutnya di cek kebenarannya guna menjamin keabsahan data. Tingkat kepercayaan hasil-hasil penelitian ditempuh dengan cara terpenuhinya criteria kredibilitas atau validitas internal, transferabilitas atau validitas eksternal, dependabilitas atau reliabilitas dan konfirmabilitas atau objektivitas. ${ }^{13}$

\section{Hasil Penelitian}

\section{Pendidikan karakter berbasis HOTS di SD IT Bunayya Lhokseumawe}

Pengembangan HOTS bagi siswa di sekolah SD IT BUNAYYA ini sangat penting untuk mengembangkan secara komprehensif kemampuan dan keterampilan siswa dalam hal berpikir kritis, sistematis, logis, aplikatif, analitis, evaluatif, kreatif, pemecahan masalah, dan pengambilan keputusan secara jujur, percaya diri, bertanggung jawab dan mandiri. Dengan kemampuan ini, siswa dapat menentukan sikap dan perilaku yang baik, dan apabila perilaku baik ini senantiasa dilakukan secara konsisten maka akan terbentuk karakter yang baik pada diri siswa. Selai itu, siswa juga akan mampu berkompetisi dalam dunia

\footnotetext{
12. Miles, M.B. \&Huberman, A. M. Analisisdata Kualitatif (Terjemahan tjetje prohen dirohidi). (Jakarta: Ui-Press, 1992),129.

${ }^{13}$ Nasution, S., Asas-Asaskurikulum (Edisikedua),(Jakarta: Bumiaksara, 2010), 32.
} 
global. Di sinilah peran HOTS dalam pembentukan karakter yang baik (good character) bagi siswa.

Dengan demikian, apabila HOTS ini dikembangka nmelalui model AFL berbasis HOTS pada siswa, maka di harapkan siswa memperoleh pembinaan dalam keterampilan berpikir tingkat tinggi maupun dalam penguasaan materi subjek dan pembentukan good character yang akan berguna bagi pengembangan akhlaknya kelak. Pengembangan HOTS dan pembentukan good character bagi siswa melalui penerapan AFL berbasis HOTS tersebut di atas, di dukung oleh hasil penelitian Barak \& Dori yang meneliti tentang bagaimana meningkatkan HOTS siswa calon guru sains melalui penilaian yang ditanamkan (embedded assessment) dalam pembelajaran. Hasil penelitian Barak dan Dori tersebut menemukan bahwa dengan menerapkan sebuah penilaian yang terintegrasi dalam pembelajaran, maka dapat meningkatkan HOTS siswa.

Dengan demikian, model AFL berbasis HOTS dapat diaplikasikan langsung dalam pelaksanaan pembelajaran di sekolah sebagai salah satu strategi dalam pengembangan HOTS dan pembentukan good character siswa. Dengan kata lain, penerapan AFL berbasis HOTS ini dapat digunakan sebagai salah satu strategi pendidikan karakter di sekolah. ${ }^{14}$

HOTS merupakan keterampilan penting untuk keberhasilan studi, bekerja, dan hidup di era informasi dan teknologi abad ke-21. HOTS dan komponennya ini dapat di kembangkan dan digunakan dengan baik ketika mempelajari suatu pengetahuan dan menyelesaikan serta mensikapi sebuah permasalahan. Guru dapat mendorong siswa untuk menggunakan HOTS tersebut dalam setiap kegiatan pembelajaran, baik dalam diskusi, praktikum, maupun kegiatan pembelajaran lainnya, dan siswa diberi kesempatan untuk mengevaluasi sendiri kemampuannya. Mengingat hal di atas, dalam konteks mengembangkan HOTS dan good character siswa, maka sistem penilaiannya harus terintegrasi dalam pembelajaran dan mengarahp ada pengembangan kemampuan berpikirkritis.

\footnotetext{
${ }^{14}$ Barak, M. \&Dori, Y.J. 2009.Enhancing Higher Order Thinking Skills Among Inservice Science Teachers Via Embedded Sssessment.Published Online: 28 July 2009. Springer Science+ Business Media, B.V. 2009: J Sci Teacher Educ (2009). 20: 459-474. Doi: 10.1007/S 10972-009-9141-Z.
} 
Mengapa? Bagaimana? Inilah dua pertanyaan kunci yang harus senantiasa hadir dalam kajian pembelajaran dan penilaian berbasis HOTS.

Oleh karena itu, rangkaian kegiatan penilaian tersebut mutlak diarahkan kepada pengembangan kemampuan berpikir kritis, logis, sistemats, analisis, sintesis dan mencipta, evaluative, dan pemecahan masalah, serta pembentukan sikap dan perilaku positif siswa. Karakteristik penilaian berbasis HOTS antara lain sebagai berikut. (1) Proses penilaian menitikberatkan pada pengembangan kemampuan berpikir kritis, logis, analitis, sintesis, evaluasi, dan pemecahan masalah, bukan sekedar menghafal atau mengingat. (2) Guru dapat memberikan permasalahan kepada siswa sebagai bahan diskusi dan pemecahan masalah sehingga dapat merangsang aktivitas berpikir. (3) Kegiatan penilaian dapat dilakukan melalui kegiatan diskusi, kegiatan lapangan, praktikum, menyusun laporan praktikum, dan siswa diberi kesempatan untuk mengevaluasi sendiri kemampuannya. (4) Penilaian dapat meningkatkan sikap dan perilaku positif siswa yang mencakup motivasi belajar, kejujuran, kemandirian, percayadiri, kedisiplinan, serta tanggung jawab. (5) Dapat memberikan umpan balik yang mampu mengoreksi kesalahan atau mengklarifikasi kesalahan (corrective feedback) kepada siswa atau dengan kata lain menerapkan assessment for learning (AFL) berbasis HOTS.

Konteks penerapan AFL berbasis HOTS dalam pendidikan karakter di sekolah adalah penerapan AFL berbasis HOTS dalam pendidikan karakter yang terintegrasi dalam proses pembelajaran di sekolah. Dalam tulisan ini, penerapan AFL berbasis HOTS dalam proses pembelajaran di sekolah mencakup penggunaan sistem penilaian yang bersifat sebagai AFL di dalam kelas yang bertujuan untuk meningkatkan HOTS siswa, perilaku positif (good character), dan kualitas pembelajaran sesuai tujuan pembelajaran yang telah ditetapkan. Hal ini berdasarkan gagasan bahwa para siswa akan lebih meningkat HOTS dan pemahamannya dan dapat mencapai tujuan pembelajaran jika mereka memahami tujuan pembelajaran mereka dan bagaimana mereka dapat mencapai tujuan tersebut.

Mengacu pendapat dari Assessment berbasis HOTS yang efektif dalam pembelajaran di sekolah mencakup beberapa hal yaitu: (1) berbagi (sharing) 
tujuan pembelajaran dan criteria keberhasilan dengan para siswa; (2) membantu para siswa mengetahui dan mengenal standar tujuan pembelajaran; (3) menyediakan feedback yang membantu para siswa untuk mengidentifikasi bagaimana meningkatkan pembelajaran; (4) percaya bahwa setiap siswa dapat meningkatan prestasinya di bandingkan dengan prestasi sebelumnya; (5) guru dan siswa bersama-sama meninjau ulang dan merefleksi kinerja dan kemajuan yang telah dicapai oleh siswa; (6) siswa diberi kesempatan belajar teknik melakukan penilaian diri (self-assessment) untuk menemukan area yang mereka butuhkan dan meningkatkan pembelajaran; dan (7) mengenali motivasi dan self-esteem siswa untuk mencapai kemajuan dan pembelajaran yang efektif yang dapat ditingkatkan dengan teknik penilaian yang efektif.

\section{Upaya Pendidikan karakter berbasis HOTS}

Berdasarkan analisis situasi dan permasalahan yang dihadapi oleh mitra, maka solusi untuk masalah ini adalah dengan memberikan workshop berupa pelatihan kepada guru-guru tentang pembelajaran berbasis HOTS. Ada beberapa metode pembelajaran yang dapat digunakan untuk mengembangkan keterampilan berpikir tingkat tinggi (HOTS) dengan memiliki ciri-ciri antara lain menyenangkan dan menggembirakan siswa, serta membuat belajar menjadi sesuatu yang menantang untuk berpikir sehingga materi ajar menjadi mudah untuk dipahami. Untuk itu ada beberapa metode inovatif yang dapat digunakan dalam mengembangkan berpikir tingkat tinggi (HOTS) antara lain dengan metode di sekolah dasar melalui pembelajaran tematik terpadu yang menggunakan pendekatan saintifik dan metode-metode yang berupa problem based learning (PBL), problem solving, discovery-inquiry, dan project based learning. Untuk itu diharapkan guru-guru mampu memahami dan mengimplementasikan pembelajaran yang dapat mengembangkan keterampilan berpikir tingkat tinggi dengan melalui materi workshop yang diberikan.

Adapun rincian solusi yang dilakukan adalah a) memberikan pemahaman kepada guru-guru tentang model pembelajaran HOTS (Higher Order Thinking); b) memberikan pemahaman kepada guru-guru tentang pengembangan nilai-nilai karakter sebagai program PPK di sekolah; serta c) memberikan pelatihan kepada 
guru-guru tentang pembuatan Rencana Pembelajaran (RPP) dan perangkat pembelajaran seperti LKPD, media pembelajaran, bahan ajar, dan evaluasi sesuai dengan kurikulum 2013 yang berbasis HOTS (Higher Order Thinking).

Setelah diadakannya workshop berupa pelatihan kepada guru-guru sekolah dasar, hasilnya diharapkan dapat a) meningkatkan pengetahuan guruguru mengenai konsep dan teori tentang pembelajaran berbasis HOTS (Higher Order Thinking) dalam mengembangkan nilai-nilai karakter bagi siswa; b) meningkatkan kemampuan guru-guru dalam merancang pembelajaran berbasis HOTS (Higher Order Thinking) untuk mengembangkan nilai-nilai karakter bagi peserta didik, serta c) meningkatkan keterampilan guru-guru dalam mengimplementasikan pembelajaran yang sesuai dengan Kurikulum 2013. Namun, keterbatasan waktu dan tempat, hasil pelatihan belum mencapai hasil yang optimal.Untuk itu diharapkan kegiatan ini dapat dilanjutkan untuk melengkapi dari keterbatasan yang ada.

\section{Penutup}

Penguatan Pendidikan Karakter berbasis HOTS merupakan usaha pemerintah untuk membenahi sistem pendidikan.Karakter adalah pondasi utama yang merupakan tujuan pendidikan.Pembenahan sistem pendidikan juga dilakukan dengan melakukan penyempurnaan kurikulum.Kurikulum 2013 yang berlaku saat ini dengan melakukan perubahan pada standar isi dan standar penilaian.Perubahan ini membantu peserta didik untuk meningkatkan kemampuan berpikir tingkat tinggi (Higher Order Thinking Skills/HOTS) gunamempersiapkan generasi ideal yang mampu menghadapi segala tantangan abad 21.Pembelajaran dengan standar HOTS dapat tercapai melalui pembelajaran yang kontekstual dan bermakna bagi peserta didik.Pembelajaran tematik integrative yang sesuai dengan pembelajaran kontekstual dan bermakma karena pembelajaran tematik menggunakan tema sehingga lebih mudah dipelajari peserta didik.Tema yang diangkat adalah tema dalam kehidupan sehari-hari peserta didik. Pengembangan pembelajaran dengan PPK berbasis HOTS karena memberikan beberapa keuntungan bagi peserta didik, antara lain: informasi yang dipelajari dan diproses melalui proses berpikir tingkat tinggi menguatkan ingatan terhadap 
informasi tersebut, dan lebih jelas dibandingkan dengan informasi yang diproses dengan LOTS (Low Order Thinking Skills), misalnya menghafal. Sebagai contoh menghafalkan rumus dengan menjelaskan penurunan rumus atau perbedaan antara mengingat definisi suatu kata baru dengan menginternalisasi strategi.Dengan pembelajaran HOTS peserta didik tidak hanya menghafal tetapi juga memahami dan mampu menerapkan dalam kehidupan sehari-hari. 


\section{Daftar Pustaka}

Barak, M. \&Dori, Y.J. 2009. Enhancing Higher Order Thinking Skills Among Inservice Science Teachers Via Embedded Sssessment. Published Online: 28 July 2009. Springer Science+ Business Media, B.V. 2009: J Sci Teacher Educ 2009. 20: 459-474. Doi: 10.1007/S 10972-009-9141-Z.

Budi Cahyono. 2017. “Analisis Ketrampilan Berfikir Kritis Dalam Memecahkan

Masalah Ditinjau Perbedaan Gender," Aksioma, , Https://Doi.Org/10.26877/Aks.V8i1.1510.

Endang Komara. 2018. "Penguatan Pendidikan Karakter Dan Pembelajaran Abad 21," Sipatahoenan: South-East Asian Journal For Youth, Sports \& Health Education.

Https://Databoks.Katadata.Co.Id/Datapublish/2017/02/10/84-Anak-Indonesia-

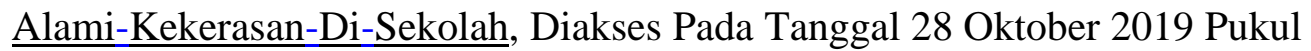
15.48 Wib.

Https://Www.Liputan6.Com/News/Read/3476521/Cegah-Tawuran-Siswa-Sd-Di-

Purwakarta-Polisi-Bakal-Pimpin-Upacara Diakses Pada Tanggal 20 Agustus 2019 Pukul 16.55

Https://Www.Liputan6.Com/News/Read/3880325/Siswi-Sd-Di-Probolinggo-

Dicabuli-Oleh-Dua-Teman-Sekelasnya. Diakses Pada Tanggal 20 Agustus 2019 Pukul 16.47 Wib.

Kemendikbud Ri, Press Workshop: 2014. Implementasi Kurikulum 2013, Kementrian Pendidikan Dan Kebudayaan Republik Indonesia.

Merta Dhewa Kusuma Et Al., “The Development Of Higher Order Thinking Skill (Hots) Instrument Assessment In Physics Study," Iosr Journal Of Research \& Method In Education (Iosrjrme), 2017, Https://Doi.Org/10.9790/73880701052632 .

Miles, M.B. \&Huberman, A. M. Analisisdata Kualitatif (Terjemahan tjetjeprohendi Rohidi). 1992. Jakarta: Ui-Press,.

Nanda Ayu Setiawati. 2017. "Pendidikan Karakter Sebagai Pilar Pembentukan Karakter Bangsa," Seminar Nasional Tahunan Fakultas Ilmu Sosial Universitas Negeri Medan. 
Nasution, S., 2010. Asas-Asaskurikulum (Edisikedua),Jakarta: Bumiaksara.

Rasid Yunus, "Transformasi Nilai-Nilai Budaya Lokal Sebagai Upaya Pembangunan Karakter Bangsa," Jurnal Penelitian Pendidikan, 2016.

Ririn Nursanti, "Manajemen Peningkatan Akhlak Mulia Di Sekolah Berbasis Islam”, Jurnal Kependidikan, Vol. Ii, No. 2, (November 2014).

Santy Andrianie, 2017. "Meningkatkan Keterampilan Empati Siswa Sekolah Dasar Melalui Paket Bimbingan Peningkatan Empati," Jurnal Bikotetik, Volume 01, Nomor 02. 